\title{
Morphology Study on Inclusion Modifications Using Mg-Ca Treatment in Resulfurized Special Steel
}

\author{
Ping Shen ${ }^{1,2} \mathbb{D}$ and Jianxun Fu ${ }^{1, *}$ \\ 1 State Key Laboratory of Advanced Special Steel; Shanghai Key Laboratory of Advanced Ferrometallurgy; \\ School of Materials Science and Engineering, Shanghai University, Shanghai 200444, China; \\ koulvpinlei@126.com \\ 2 School of Metallurgical and Ecological Engineering, University of Science and Technology Beijing, \\ Beijing 100083, China \\ * Correspondence: fujianxun@shu.edu.cn
}

Received: 20 December 2018; Accepted: 3 January 2019; Published: 9 January 2019

\begin{abstract}
In resulfurized special steel, $\mathrm{MnS}$ and $\mathrm{Al}_{2} \mathrm{O}_{3}$ are two main inclusions that deteriorate fatigue life and machinability. It is important that these two inclusions should be well controlled to increase steel quality and usage performance. In the present study, a $\mathrm{Mg}-\mathrm{Ca}$ treatment was employed to modify the $\mathrm{MnS}$ and $\mathrm{Al}_{2} \mathrm{O}_{3}$ inclusions in resulfurized steels to reduce detrimental effects on fatigue life and machinability. In the laboratory study, $\mathrm{Ni}-\mathrm{Mg}$ alloy was added to $16 \mathrm{MnCrS5}$ and $49 \mathrm{MnVS} 3$ steels. Both $\mathrm{Al}_{2} \mathrm{O}_{3}$ and $\mathrm{CaO}-\mathrm{Al}_{2} \mathrm{O}_{3}$ were gradually modified to $\mathrm{MgO} \cdot \mathrm{Al}_{2} \mathrm{O}_{3}$ and $\mathrm{MgO}$, being surrounded by $\mathrm{MnS}$, that is, a complex inclusion with an oxide core and sulfide outer layer was formed. The amount of the complex inclusion increased with $\mathrm{Mg}$ content. In the hot forging experiment, non-Mg treated inclusions were in the morphology of long strip, while those with $\mathrm{Mg}$ treatment were seen to be less deformed with spherical morphology of low aspect ratio in which case inclusions had less effect on steel mechanical properties. The $\mathrm{Mg}-\mathrm{Ca}$ treatment was also applied to the manufacture of resulfurized special steel in steel plants. The scanning electron microscope-energy dispersive spectrometer and statistical results agreed well with those in the laboratory studies.
\end{abstract}

Keywords: modification; $\mathrm{MnS} ; \mathrm{Al}_{2} \mathrm{O}_{3}$; inclusion; $\mathrm{Mg}-\mathrm{Ca}$ treatment

\section{Introduction}

Resulfurized steels, such as non-quenched and tempered steel $(S=\sim 0.02-0.065 \%$ [1]), gear steel ( $\mathrm{S}=\sim 0.015-0.035 \%$ [2]), etc., are widely used in hot forging automotive components of power transmission system. According to the quality requirement of automotive components, the resulfurized special steel should have excellent fatigue life [3] and good machinability, both of which are strongly affected by the inclusions in the steel. Manganese sulfide is the main inclusion in the resulfurized special steel. It has a good plasticity and can be easily deformed into a long stripe after rolling, which causes the anisotropy of steel properties, therefore reducing the fatigue life [4,5], and is also harmful to the machinability of steels [6]. The morphology control of sulfide is the key to the improvement of steel properties. Sulfide with a spherical or spindle morphology is usually beneficial for the mechanical property and machinability of steels [7]. On the other hand, $\mathrm{Al}_{2} \mathrm{O}_{3}$ is another kind of inclusion generated by the $\mathrm{Al}$ deoxidation in molten steels. It can become the crack source or promote the crack propagation under alternating load in service, which suppresses the anti-fatigue property $[8,9]$. In addition, $\mathrm{Al}_{2} \mathrm{O}_{3}$ can cause excessive tool wear in the machining process.

The $\mathrm{MnS}$ and $\mathrm{Al}_{2} \mathrm{O}_{3}$ inclusions are two aspects that limit the application of steels. If the detrimental effect of both $\mathrm{MnS}$ and $\mathrm{Al}_{2} \mathrm{O}_{3}$ can be eliminated, such as forming a complex inclusion with an oxide core and sulfide outer layer, the deformation of sulfide will be restricted [7], and the oxide will not 
directly cause the cracks of steels. This will result in the remarkable quality improvement of steels. Based on this idea, Ca treatment and Mg treatment are two manufacturing techniques that have been used in the refining process.

Calcium treatment is usually used in Al-killed steels to modify the $\mathrm{Al}_{2} \mathrm{O}_{3}$ inclusion to liquid calcium aluminates, which can prevent the nozzle clogging [10]. Besides, the calcium aluminates is softer than $\mathrm{Al}_{2} \mathrm{O}_{3}$, and has less of a possibility for the formation of cracks [11]. In the resulfurized steel, $\mathrm{Ca}$ is also used to modify the MnS inclusion. Calcium dissolves into MnS and reduces the plasticity of $\mathrm{MnS}$, restricting the deformation of MnS during the rolling process [12]. In the solidification process of steels, sulfide has a strong tendency to precipitate around oxide inclusions, forming complex inclusions. Lind and Holappa [11] investigated the reaction between $\mathrm{CaO}$ and $\mathrm{Al}_{2} \mathrm{O}_{3}$ as well as between calcium and $\mathrm{Al}_{2} \mathrm{O}_{3}$ inclusions in steel melts, and put forward the mechanism and kinetics of alumina inclusion modification. Qiao et al. [13] studied the thermodynamics on the modification of inclusions by $\mathrm{Ca}$ treatment and stated the control target of Ca content to attain the most ideal effect. Blais et al. [14] studied the effect of different $\mathrm{Ca} / \mathrm{S}$ ratios on the modification of inclusions and proposed that an optimum Ca/S ratio of 0.70 allowed modification of the mean shape factor of MnS inclusions; the further increase of Ca concentration did not affect the morphology of inclusions. Although, inclusions in steels can be modified by $\mathrm{Ca}$, the modification efficiency is usually not so high, meanwhile the excess addition of Ca may cause the formation of high melting point inclusion CaS [15], leading to the nozzle clogging. In the field of high-end automobiles, the Ca treatment process still cannot meet the requirements of steel property.

Magnesium treatment is another refining process. Compared with Ca treatment, $\mathrm{Mg}$ has a stronger affinity for oxygen and sulfur, and the steel shows a better cleanliness after $\mathrm{Mg}$ treatment [16]. The $\mathrm{Al}_{2} \mathrm{O}_{3}$ can be modified to $\mathrm{MgO} \cdot \mathrm{Al}_{2} \mathrm{O}_{3}$ and $\mathrm{MgO}$, which have a smaller size than that after $\mathrm{Ca}$ treatment and distribute dispersedly [17]. The tiny and randomly distributed $\mathrm{MgO} \cdot \mathrm{Al}_{2} \mathrm{O}_{3}$ and $\mathrm{MgO}$ usually have few influences on steel properties. Additionally, $\mathrm{MgO} \cdot \mathrm{Al}_{2} \mathrm{O}_{3}$ and $\mathrm{MgO}$ are excellent heterogeneous nucleating agents [18] for the precipitation of MnS. Similar to $\mathrm{Ca}, \mathrm{Mg}$ can also dissolve into MnS, forming the (Mn,Mg)S solid solution. Zhang et al. [18] reported that MnS preferred to precipitate on the surface of $\mathrm{Mg}$-containing oxide inclusions. The inclusion changed in different orders in the steel with different sulfur contents. Fu et al. [19] studied the modification of inclusions with $\mathrm{Mg}$ treatment in $35 \mathrm{CrNi3MoV}$ steel, and found that elongated $\mathrm{MnS}$ inclusions was replaced by small ellipsoidal MgS.MgO and MgS.MnS.MgO. In the research of Tsunekage and Tsubakino [7], the morphology of inclusions and the mechanical property in the resulfurized steel after $\mathrm{Mg}$ treatment were studied. In the steel, $(\mathrm{Mn}, \mathrm{Mg}) \mathrm{S}$ with a fusiform morphology was generated, and the transverse impact properties were remarkablely improved, while the longitudinal impact properties were not affected. The $\mathrm{Mg}$ treatment can achieve a better inclusion modification; however, the reaction in the molten steel with the adding of $\mathrm{Mg}$ is usually too violent to control in the refining process. Besides, the $\mathrm{Mg}$ may also cause the nozzle clogging. Therefore, it is not widely used yet.

Both $\mathrm{Mg}$ treatment and $\mathrm{Ca}$ treatment can effectively modify the $\mathrm{MnS}$ and $\mathrm{Al}_{2} \mathrm{O}_{3}$ inclusions in steels. Nevertheless, the Ca treatment has low modification efficiency, while the $\mathrm{Mg}$ treatment may cause the nozzle clogging. Besides, the previous studies mainly focused on the composition change of inclusions, and the morphology change was not well studied. Therefore, Mg-Ca treatment was employed for resulfurized special steel in the present study to achieve a better modification of inclusions without nozzle clogging. The effect of modification on the morphology change of inclusions was systematically studied. The experiments were conducted in both laboratory and industrial conditions. The modification mechanism of inclusions was proposed.

\section{Laboratory Study}

In this section, two kinds of steels, non-quenched and tempered steel 49MnVS3 and gear steel $16 \mathrm{MnCrS5}$, were studied. The chemical composition of the steels is shown in Table 1 . The raw materials used for the laboratory study were taken from the center of the continuous casting slabs. During the 
manufacture of steels, the molten steels were already treated with $\mathrm{Ca}$ in the refining process. The $\mathrm{Ca}$ content in 16MnCrS5 and 49MnVS3 was 12 ppm and 6 ppm, respectively.

Table 1. The chemical composition of the samples (wt \%).

\begin{tabular}{ccccccccccccccc}
\hline Composition & $\mathbf{F e}$ & $\mathbf{C}$ & $\mathbf{S i}$ & $\mathbf{M n}$ & $\mathbf{P}$ & $\mathbf{S}$ & $\mathbf{A l}_{\mathbf{t}}$ & $\mathbf{C r}$ & $\mathbf{V}$ & $\mathbf{T i}$ & $\mathbf{N i}$ & $\mathbf{M g}$ & $\mathbf{C a}$ & $\mathbf{O}$ \\
\hline 16MnCrS5 & balance & 0.16 & 0.16 & 1.18 & 0.0065 & 0.0278 & 0.031 & 1.023 & - & - & - & $<0.0005$ & 0.0012 & 0.0019 \\
49MnVS3 & balance & 0.47 & 0.35 & 0.92 & 0.013 & 0.047 & 0.012 & 0.2 & 0.1 & 0.025 & - & $<0.0005$ & 0.0006 & 0.0015 \\
Ni-Mg alloy & 0.85 & 0.56 & 0.11 & - & - & - & - & - & - & - & 74.19 & 24.29 & - & - \\
\hline
\end{tabular}

\subsection{Sample Preparation}

In each experiment, an approximate 500-600 g steel sample was put in a corundum crucible with inner diameter of $53 \mathrm{~mm}$ and height of $120 \mathrm{~mm}$, and protected by an outer graphite crucible. Then specimens were placed in the constant temperature zone of a vertical tube resistance furnace. The experimental apparatus is shown schematically in Figure 1. Argon gas was purged into the reaction tube at a flow rate of $1 \mathrm{~L} / \mathrm{min}$. Both the graphite crucible and Ar gas were aimed to prevent the oxidation of samples. The temperature was raised to $1000^{\circ} \mathrm{C}$ at a heating rate of $8{ }^{\circ} \mathrm{C} / \mathrm{min}$ and then to $1600{ }^{\circ} \mathrm{C}$ at a heating rate of $4{ }^{\circ} \mathrm{C} / \mathrm{min}$. The temperature was held at $1600{ }^{\circ} \mathrm{C}$ for $20 \mathrm{~min}$, ensuring the complete melting of the steel. Then $\mathrm{Ni}-\mathrm{Mg}$ alloy wrapped by iron foil was added into the molten steel. The composition of Ni-Mg alloy is listed in Table 1. Five minutes later, the molten steel was stirred with a molybdenum stick. Another $10 \mathrm{~min}$ was maintained to ensure the composition homogeneity of the molten steel. Thereafter, the steel was cooled down at a cooling rate of $4{ }^{\circ} \mathrm{C} / \mathrm{min}$. The temperature difference between the steel sample inside the corundum tube and the thermocouple outside the corundum tube is approximately $50{ }^{\circ} \mathrm{C}$. Therefore, the temperature of the steel sample was $1550{ }^{\circ} \mathrm{C}$ when the furnace showed $1600{ }^{\circ} \mathrm{C}$.

After the smelting trial, the $\mathrm{Mg}$ content in each ingot was measured by inductively coupled plasma-optical emission spectrometry (ICP-OES, tested by NCS Testing Technology CO., LTD., Beijing, China), the result is shown in Table 2. For comparison, the re-melted steel sample without adding $\mathrm{Ni}-\mathrm{Mg}$ alloy is also listed in Table 2. The Mg content in the original steel sample is less than 5 ppm, according to the following analysis of inclusions by EDS (Energy Dispersive Spectroscopy, scanning electron microscope, Phenom, Eindhoven, The Netherlands), few Mg can be detected. Thus, the Mg content is roughly considered to be $0 \mathrm{ppm}$ in the following discussions. Since the original steel sample was already treated by $\mathrm{Ca}$, the re-melted sample is a Ca treated sample, while that with the addition of $\mathrm{Ni}-\mathrm{Mg}$ alloy is an $\mathrm{Mg}-\mathrm{Ca}$ treated sample.

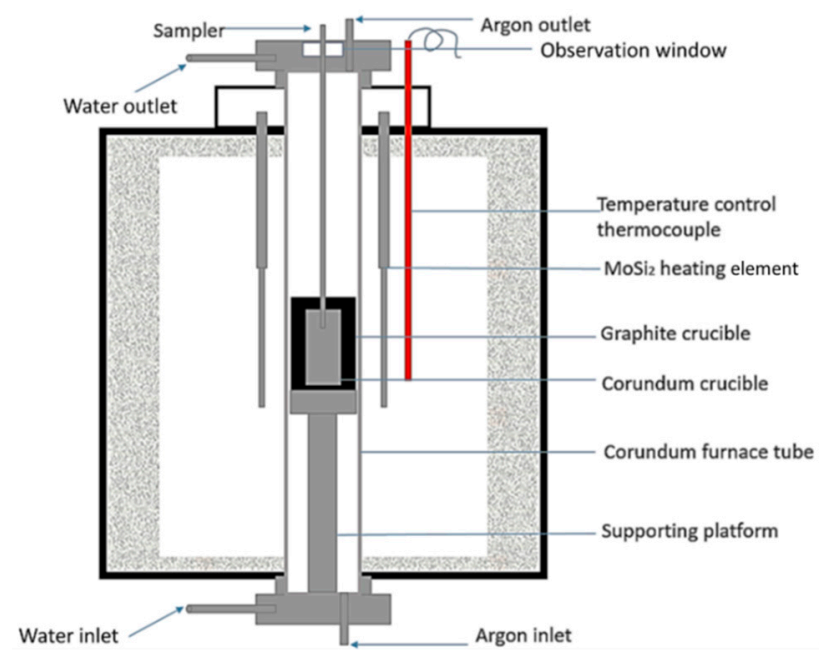

Figure 1. Schematic of the experimental apparatus. 
Table 2. Mg content in each steel sample (ppm).

\begin{tabular}{cccccc}
\hline Sample No. & $\mathbf{1}$ & $\mathbf{2}$ & $\mathbf{3}$ & $\mathbf{4}$ & $\mathbf{5}$ \\
\hline 16MnCrS5 & $<5$ & 8 & 15 & 19 & 35 \\
49MnVS3 & $<5$ & 7 & 10 & 19 & 22 \\
\hline
\end{tabular}

In the center of each ingot, a steel sample with a detecting area of $10 \mathrm{~mm} \times 10 \mathrm{~mm}$ was machined. After polishing, the steel samples were ultrasonic cleaned in ethyl alcohol. These samples were prepared for SEM-EDS analysis. Except for the observations via two-dimensional morphology of inclusions on the polished surface of steel samples, the non-aqueous solution electrolytic etching method was also used to obtain the stereoscopic structure of the inclusions for the three-dimension morphology observation.

\subsection{Analysis of Inclusions}

The inclusions in both $49 \mathrm{MnVS3}$ and 16MnCrS5 steels were detected by SEM-EDS. With the increase of $\mathrm{Mg}$ content in the steel, the variation of inclusions for both steels was similar. For the convenience of discussion, the SEM-EDS result of only 16MnCrS5 steel is discussed. In the steels with different $\mathrm{Mg}$ contents, both single MnS and complex inclusions existed. Figure 2 shows the compositions of complex inclusions. In the re-melted sample, the oxide core was mainly composed of $\mathrm{CaO}-\mathrm{Al}_{2} \mathrm{O}_{3}$ or $\mathrm{Al}_{2} \mathrm{O}_{3}$. With adding of $\mathrm{Mg}$, the oxide core transformed into $\mathrm{MgO} \cdot \mathrm{Al}_{2} \mathrm{O}_{3}$. With the further increase of $\mathrm{Mg}$ content, $\mathrm{MgO}$ started to generate and became the core of complex inclusion. In the outer MnS layer, there was a small amount of $\mathrm{Ca}$ and/or Mg.

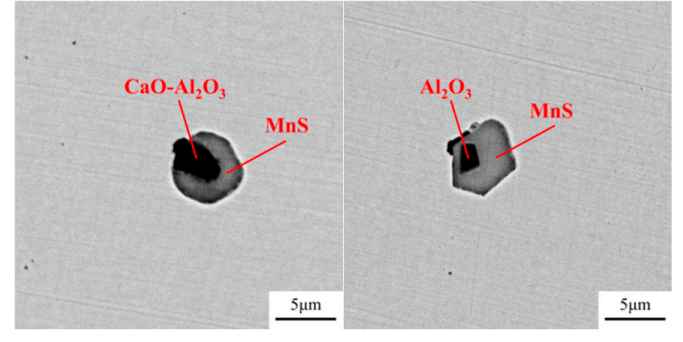

(a)

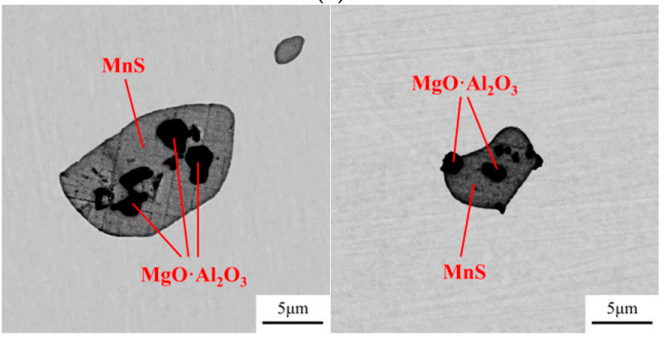

(c)

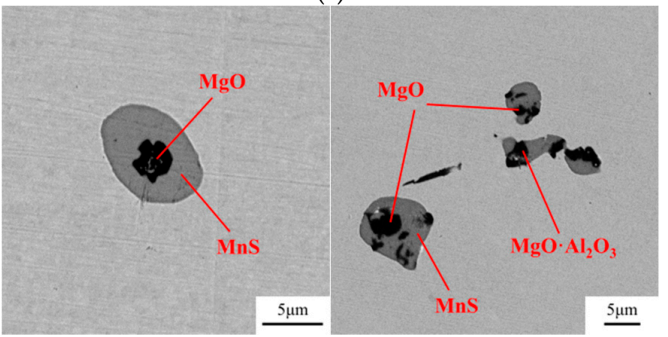

(e)

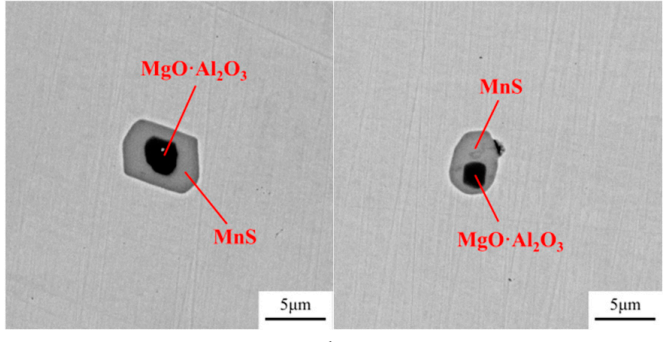

(b)

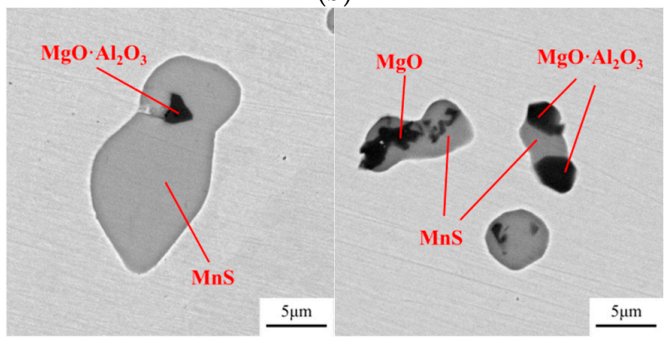

(d)

Figure 2. Compositions of the complex inclusions in $16 \mathrm{MnCrS5}$ steels with (a) 0 ppm Mg; (b) 8 ppm $\mathrm{Mg}$; (c) 15 ppm Mg; (d) 19 ppm Mg; (e) 35 ppm Mg. 
In order to distinguish the ratio of different kinds of inclusions, more than 100 inclusions were detected with EDS in each steel sample. The main inclusion in the current specimens was MnS, of which some were pure single-phase $\mathrm{MnS}$, while some were MnS with oxide cores. Figure 3a shows the counted result for the gear steel 16MnCrS5. The composition and number percentage of each kind of inclusion did not show a big difference between the original billet and the re-melted sample, indicating that the re-melting process barely affected the composition of inclusions. The main inclusions in the original billet and re-melted steel were single $\mathrm{MnS}, \mathrm{MnS}$ with an $\mathrm{Al}_{2} \mathrm{O}_{3}$ core, and MnS with a $\mathrm{CaO}-\mathrm{Al}_{2} \mathrm{O}_{3}$ core. With the increase of $\mathrm{Mg}$ content in the steel, the $\mathrm{Al}_{2} \mathrm{O}_{3}$ and $\mathrm{CaO}-\mathrm{Al}_{2} \mathrm{O}_{3}$ gradually changed to $\mathrm{MgO} \cdot \mathrm{Al}_{2} \mathrm{O}_{3}$ and $\mathrm{MgO}$, which were usually distributed with smaller size [16]. Manganese sulfide did not usually exist in molten steel at $1550{ }^{\circ} \mathrm{C}$. During the solidification of steels, MnS precipitated from the molten steel in the form of heterogeneous nucleation. The oxide inclusions in the steel became the heterogeneous nucleation points for MnS. The more oxide cores, the larger number of complex inclusions. Thus, the amount of single MnS continuously decreased from 93.9 to $53.1 \%$ with the increase of $\mathrm{Mg}$ content from $0 \mathrm{ppm}$ to $35 \mathrm{ppm}$. The complex inclusions usually had a higher hardness than MnS and showed less deformation during the rolling process.

In the $49 \mathrm{MnVS3}$ steel, except for the MnS and oxide inclusion, there was also another kind of inclusion, that was $(\mathrm{Ti}, \mathrm{V})(\mathrm{C}, \mathrm{N})$. However, only single $\mathrm{MnS}$ and $\mathrm{MnS}$ with an oxide core were counted, the result is shown in Figure $3 \mathrm{~b}$. The inclusions in the re-melted sample was also similar to that in the original billet. In both samples, there was a small amount of $\mathrm{MnS}$ with an $\mathrm{Al}_{2} \mathrm{O}_{3}$ or $\mathrm{CaO}-\mathrm{Al}_{2} \mathrm{O}_{3}$ core. After adding 7 ppm $\mathrm{Mg}$, the $\mathrm{Al}_{2} \mathrm{O}_{3}$, and $\mathrm{CaO}-\mathrm{Al}_{2} \mathrm{O}_{3}$ disappeared. Meanwhile, the spinel phase $\mathrm{MgO} \cdot \mathrm{Al}_{2} \mathrm{O}_{3}$ was generated. When the $\mathrm{Mg}$ content increased, the variation of inclusion type and number percentage of each kind of inclusion were similar to that in $16 \mathrm{MnCrS5}$ steel, where the amount of complex inclusion was obviously increased.

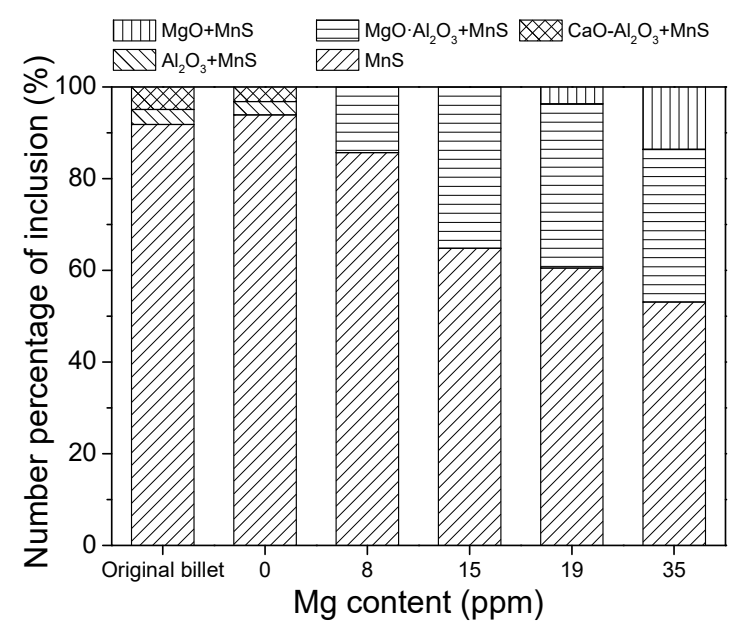

(a)

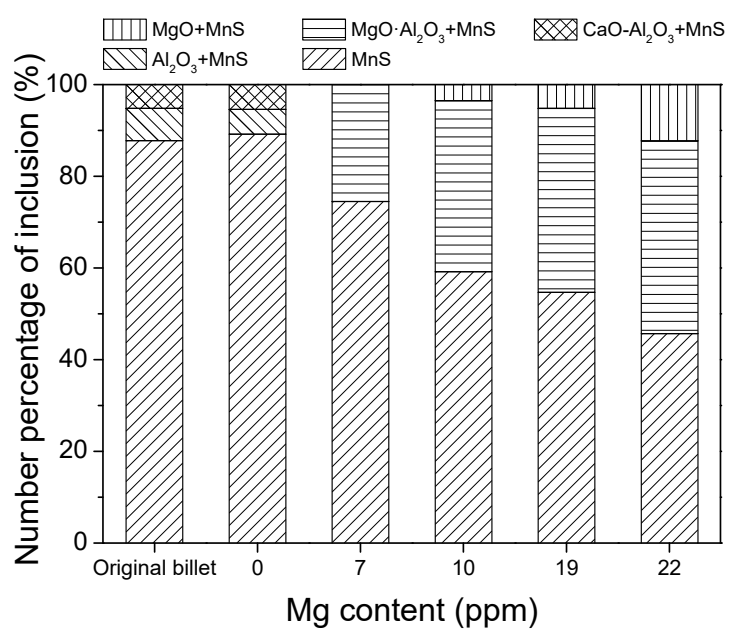

(b)

Figure 3. Number percentage of different kinds of inclusions in the steels: (a) 16MnCrS5; (b) 49MnVS3.

After electrolytic etching of steel samples in non-aqueous solution, the three-dimension morphology of inclusions was observed with SEM. Figure 4 shows the SEM images of inclusions in steels with different $\mathrm{Mg}$ contents. In the re-melted sample, most of the inclusions were type II inclusions with a dendritic shape [20]. With the increase of Mg content, this kind of inclusion gradually transformed to type III or type I inclusion with an angular or spherical shape. Therefore, the modification of inclusions by $\mathrm{Mg}$ had a prominent effect on the morphology of inclusions. 


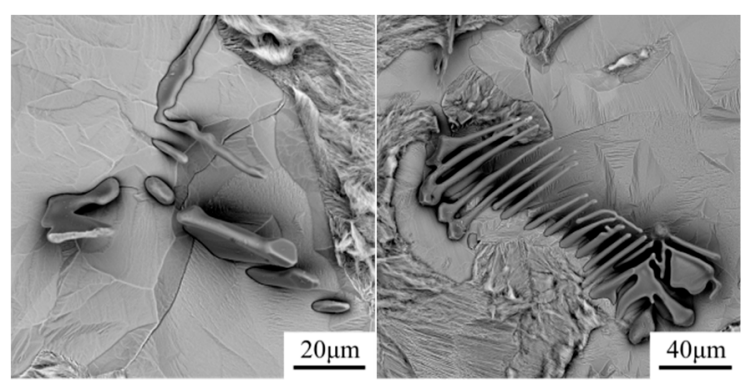

(a)

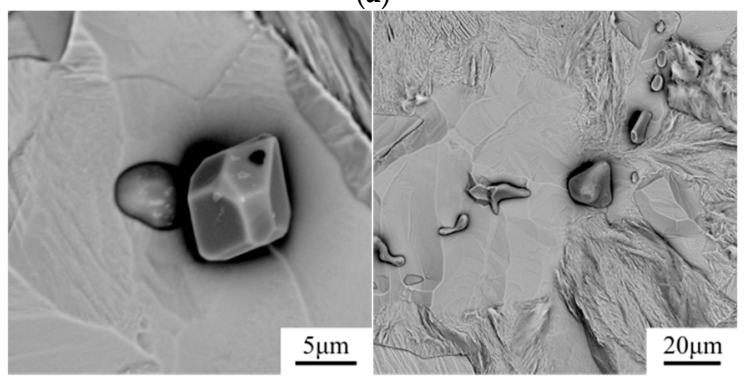

(c)

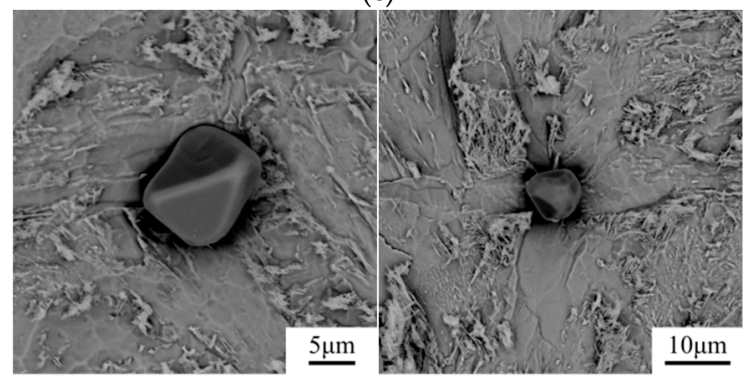

(e)

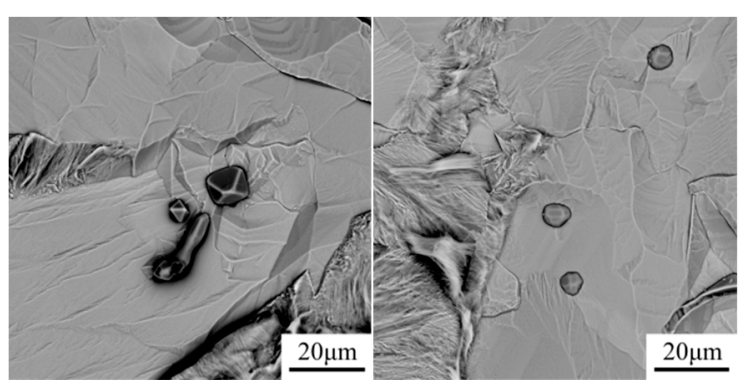

(b)

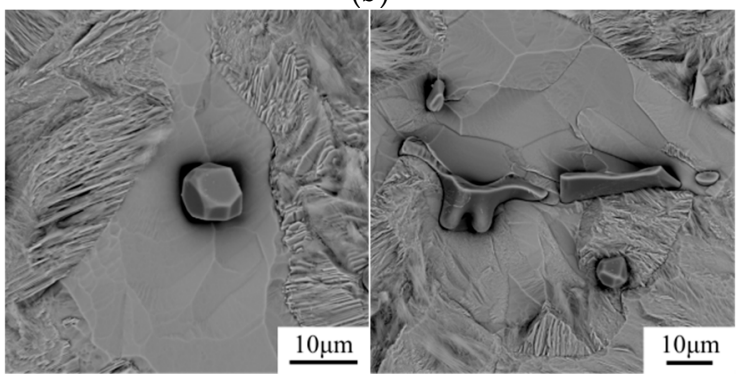

(d)

Figure 4. Three-dimension morphology of inclusions in $16 \mathrm{MnCrS5}$ steels with (a) $0 \mathrm{ppm} \mathrm{Mg}$; (b) $8 \mathrm{ppm}$ $\mathrm{Mg}$; (c) 15 ppm Mg; (d) 19 ppm Mg; (e) 35 ppm Mg.

\subsection{Hot Forging Experiment}

In order to analyze the deformability of inclusions after $\mathrm{Mg}-\mathrm{Ca}$ treatment in the hot rolling process, the hot forging experiment was conducted for $16 \mathrm{MnCrS5}$ steel to simulate the hot rolling process. Steel ingots were forged in the radial direction, therefore the MnS inclusion was elongated to the transverse-axial direction, which is similar to the deformation of $\mathrm{MnS}$ in the rolling direction for the steel slab. Steel samples with $25 \mathrm{~mm}$ in diameter and $35 \mathrm{~mm}$ in height were heated to $900{ }^{\circ} \mathrm{C}$ at a heating rate of $5{ }^{\circ} \mathrm{C} / \mathrm{min}$. Then the steel samples were forged at this temperature for $5 \mathrm{~min}$ to reach the same deformation. Subsequently, the forged samples were cooled down to room temperature. Then the steel samples along the transverse-axis direction were prepared for the optical microscope (Carl Zeiss, Oberkochen, Germany) observation and inclusions were counted with Image Pro Plus 6.0 (Media Cybernetics, Rockville, MD, USA).

The inclusions after the hot forging experiment were captured by an optical microscope, the images are shown in Figure 5. The MnS inclusion without an oxide core was more likely to deform into a long strip. This kind of inclusion existed in all samples. However, the number of long-strip MnS decreased with the increase of $\mathrm{Mg}$ content. On the other hand, the complex inclusions with an oxide core showed less deformation. The aspect ratio of inclusions was counted with Image Pro Plus 6.0. It was roughly divided into three regions, as shown in Figure 6. The inclusions with an aspect ratio of $\sim 1-3$ was usually considered to be harmless to the steel properties [21]. The number percentage of inclusions with this morphology was increased from 31 to $65 \%$ when the $\mathrm{Mg}$ content increased from $0 \mathrm{ppm}$ to $35 \mathrm{ppm}$. Obviously, the addition of $\mathrm{Mg}$ had a significant influence on preventing the deformation of MnS. 


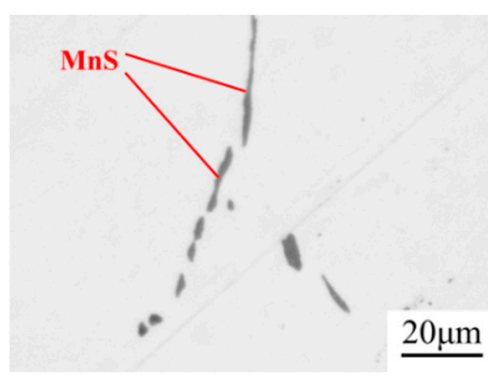

(a)

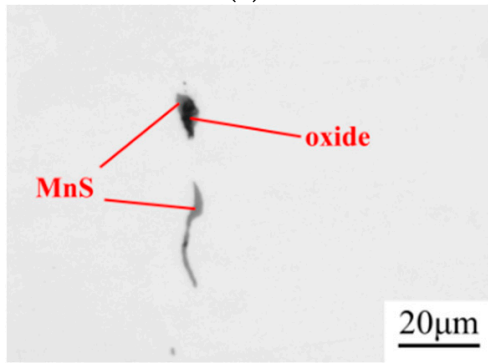

(d)

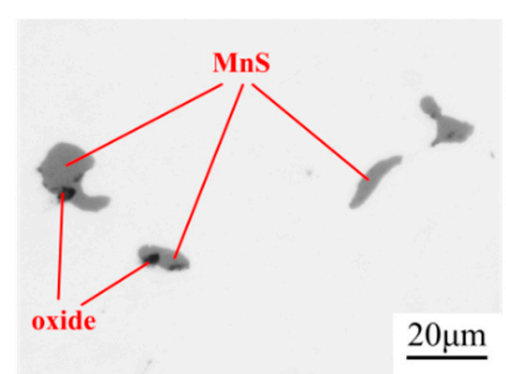

(b)

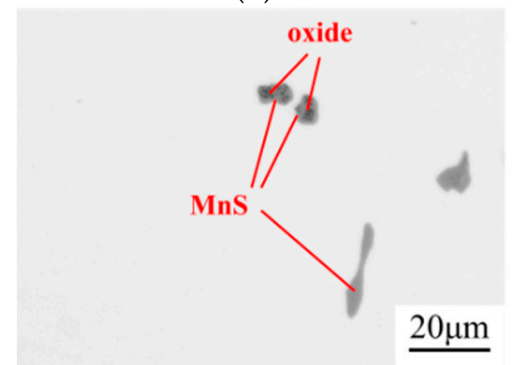

(e)

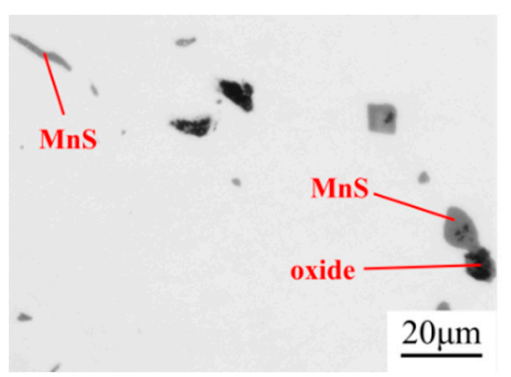

(c)

Figure 5. Inclusions in the 16MnCrS5 steel after forging (a) 0 ppm Mg; (b) 8 ppm Mg; (c) 15ppm Mg; (d) 19 ppm Mg; (e) 35 ppm Mg.

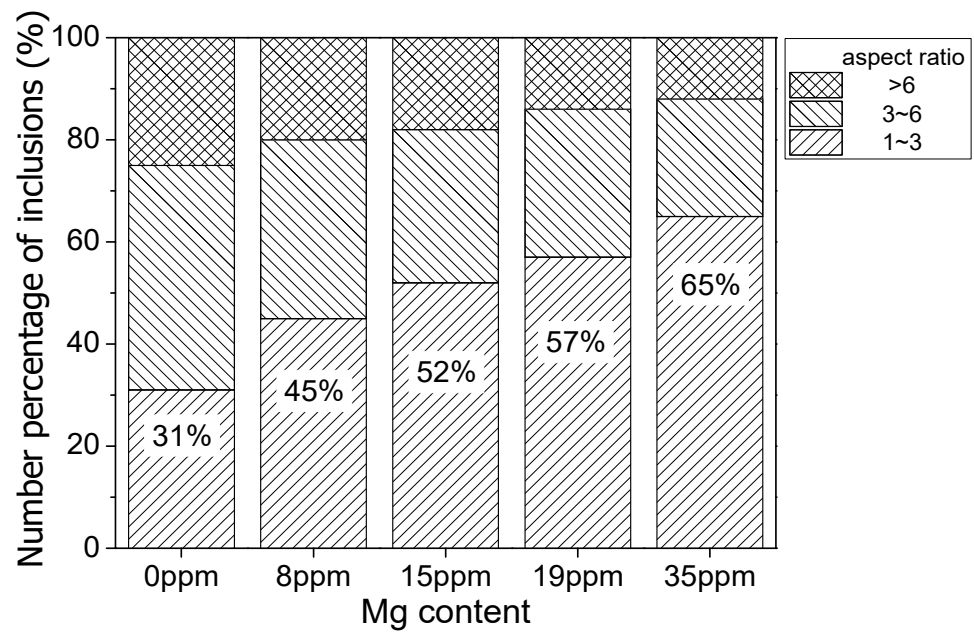

Figure 6. Number percentage of inclusions in $16 \mathrm{MnCrS5}$ steel in different aspect ratio ranges.

In the present study, the plasticity of the MnS was reduced by the following two mechanisms:

(1) Calcium or magnesium dissolved into $\mathrm{MnS}$, forming (Mn,Ca)S, (Mn,Mg)S or (Mn,Ca,Mg)S solid solution, which had a lower plasticity than pure MnS [5,12]. During the rolling process, the inclusion showed less deformation performance [7] and kept a low aspect ratio.

(2) Compared with the single MnS inclusion, the oxide inclusion had a higher strength and hardness [22]. The oxide restricted the deformation of $\mathrm{MnS}$ inclusion during the rolling process when it became the core of MnS. Magnesium modified the $\mathrm{Al}_{2} \mathrm{O}_{3}$ inclusions, forming large quantity and dispersive distributed $\mathrm{MgO} \cdot \mathrm{Al}_{2} \mathrm{O}_{3}$ spinel inclusion or $\mathrm{MgO}$ inclusion with a relatively small size $[18,23]$. It was reported that $\mathrm{MgO} \cdot \mathrm{Al}_{2} \mathrm{O}_{3}$ and $\mathrm{MgO}$ inclusion had a much weaker tendency to aggregate than $\mathrm{Al}_{2} \mathrm{O}_{3}$ inclusions $[17,18,24]$. During the solidification of steels, $\mathrm{MnS}$ took the tiny spinel inclusion or $\mathrm{MgO}$ inclusion as the heterogeneous nucleation point, forming the complex inclusion. The increase of $\mathrm{Mg}$ content caused the proportion increase of this kind of inclusion, which was beneficial to restrict more inclusions to deform into a long strip. 


\section{Mechanism of the Modification of Inclusions}

\subsection{Modification of Oxide and MnS Inclusions}

Both $\mathrm{Mg}$ and $\mathrm{Ca}$ are in group two of the periodic table. There are some similarities in the modification of inclusions. Both $\mathrm{MnS}$ and $\mathrm{Al}_{2} \mathrm{O}_{3}$ inclusions can be modified by $\mathrm{Ca}$ and $\mathrm{Mg}$. At high temperature, the oxide inclusions already existed in the molten steel, while MnS precipitated in the solidification process [25]. Thus, when $\mathrm{Ca}$ or $\mathrm{Mg}$ was added into the molten steel, the oxide inclusions were first modified. During the solidification of the steel, MnS precipitated around oxide inclusions, forming complex inclusions with inner oxide core and outer MnS layer. Meanwhile, the MnS might also be modified to CaS, MgS or solid solutions (Mn, Ca)S, (Mn,Mg)S, (Mn, Ca, Mg)S. The detailed modification mechanisms of inclusions are discussed as follows.

When the molten steel was treated with $\mathrm{Ca}, \mathrm{Al}_{2} \mathrm{O}_{3}$ transformed to $\mathrm{CaO}-\mathrm{Al}_{2} \mathrm{O}_{3}$ with different stoichiometric ratios $[9,26,27]$. During the solidification of steels, the segregation of Mn and S caused the precipitation of $\mathrm{MnS}$, which wrapped $\mathrm{CaO}-\mathrm{Al}_{2} \mathrm{O}_{3}$, as shown in Figure 7a. Meanwhile, a certain amount of Ca might dissolve into MnS, forming the (Mn, Ca)S solid solution. When the Ca content in the steel was high enough, CaS could generate in molten steel, and then wrapped by (Mn,Ca)S in the solidification process. The modification of $\mathrm{MnS}$ is shown in Figure $7 \mathrm{~b}$.

In the $\mathrm{Mg}-\mathrm{Ca}$ treated steel, $\mathrm{Al}_{2} \mathrm{O}_{3}$ was already modified by $\mathrm{Ca}$ in the raw material. After re-melting of the steel, the main oxide inclusions in the molten steel were $\mathrm{CaO}-\mathrm{Al}_{2} \mathrm{O}_{3}$, as well as a certain amount of un-modified $\mathrm{Al}_{2} \mathrm{O}_{3}$. After the addition of $\mathrm{Mg}$, the $\mathrm{Al}_{2} \mathrm{O}_{3}$ could change to $\mathrm{MgO} \cdot \mathrm{Al}_{2} \mathrm{O}_{3}$ and $\mathrm{MgO}$, which were excellent heterogeneous nucleation point, inducing the precipitation of $\mathrm{MnS}$ on the surface of $\mathrm{MgO} \cdot \mathrm{Al}_{2} \mathrm{O}_{3}$ and $\mathrm{MgO}$. The modification of $\mathrm{Al}_{2} \mathrm{O}_{3}$ by $\mathrm{Mg}$ is shown in Figure $8 \mathrm{a}$. On the other hand, when modified by $\mathrm{Mg}$, the $\mathrm{CaO}$ in $\mathrm{CaO}-\mathrm{Al}_{2} \mathrm{O}_{3}$ inclusion might be replaced by $\mathrm{MgO}$, forming $\mathrm{CaO}-\mathrm{Al}_{2} \mathrm{O}_{3}-\mathrm{MgO}$ or $\mathrm{MgO} \cdot \mathrm{Al}_{2} \mathrm{O}_{3}$. When more $\mathrm{Mg}$ was added, the $\mathrm{CaO}-\mathrm{Al}_{2} \mathrm{O}_{3}$ might transform to $\mathrm{MgO}$. In addition, when $\mathrm{Mg}$ was added into the molten steel, part of $\mathrm{Mg}$ became the deoxidizer and reacted with the dissolved oxygen, forming $\mathrm{MgO}$ [28]. Then, the $\mathrm{MgO}$ reacted with $\mathrm{Al}_{2} \mathrm{O}_{3}$ and $\mathrm{CaO} \cdot \mathrm{Al}_{2} \mathrm{O}_{3}$. When the MnS was modified, the formation mechanism of $(\mathrm{Mn}, \mathrm{Ca}, \mathrm{Mg}) \mathrm{S},(\mathrm{Mn}, \mathrm{Mg}) \mathrm{S}$, and $\mathrm{MgS}$ was similar to that modified by $\mathrm{Ca}$. The modification schematic of inclusions is shown in Figure $8 \mathrm{~b}$. In the present study, both $\mathrm{Ca}$ and $\mathrm{Mg}$ content were not high, thus, CaS and MgS were not observed. The reaction of each modification process is listed in Table 3.

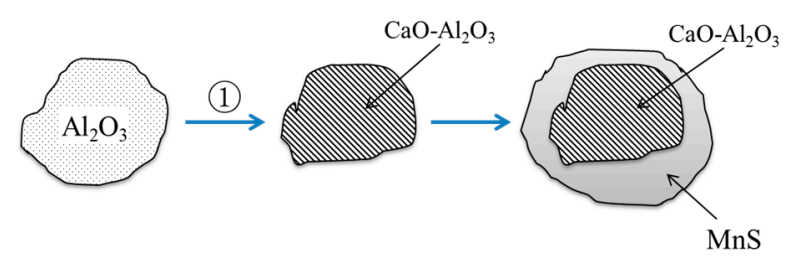

(a)

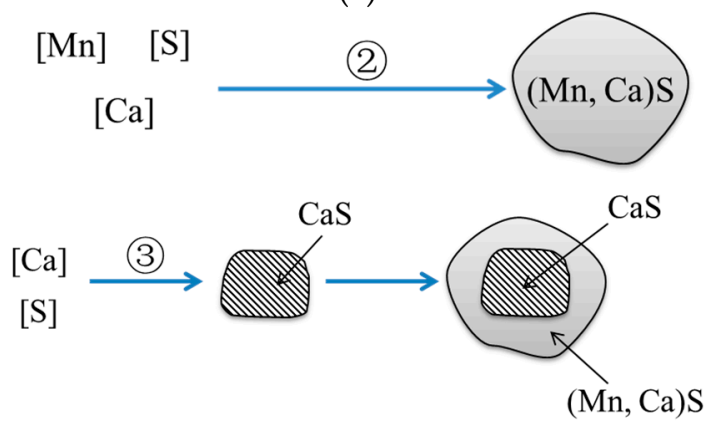

(b)

Figure 7. Mechanism of the modification of inclusions by Ca treatment: (a) modification of oxide inclusions; (b) modification of sulfide inclusions. 


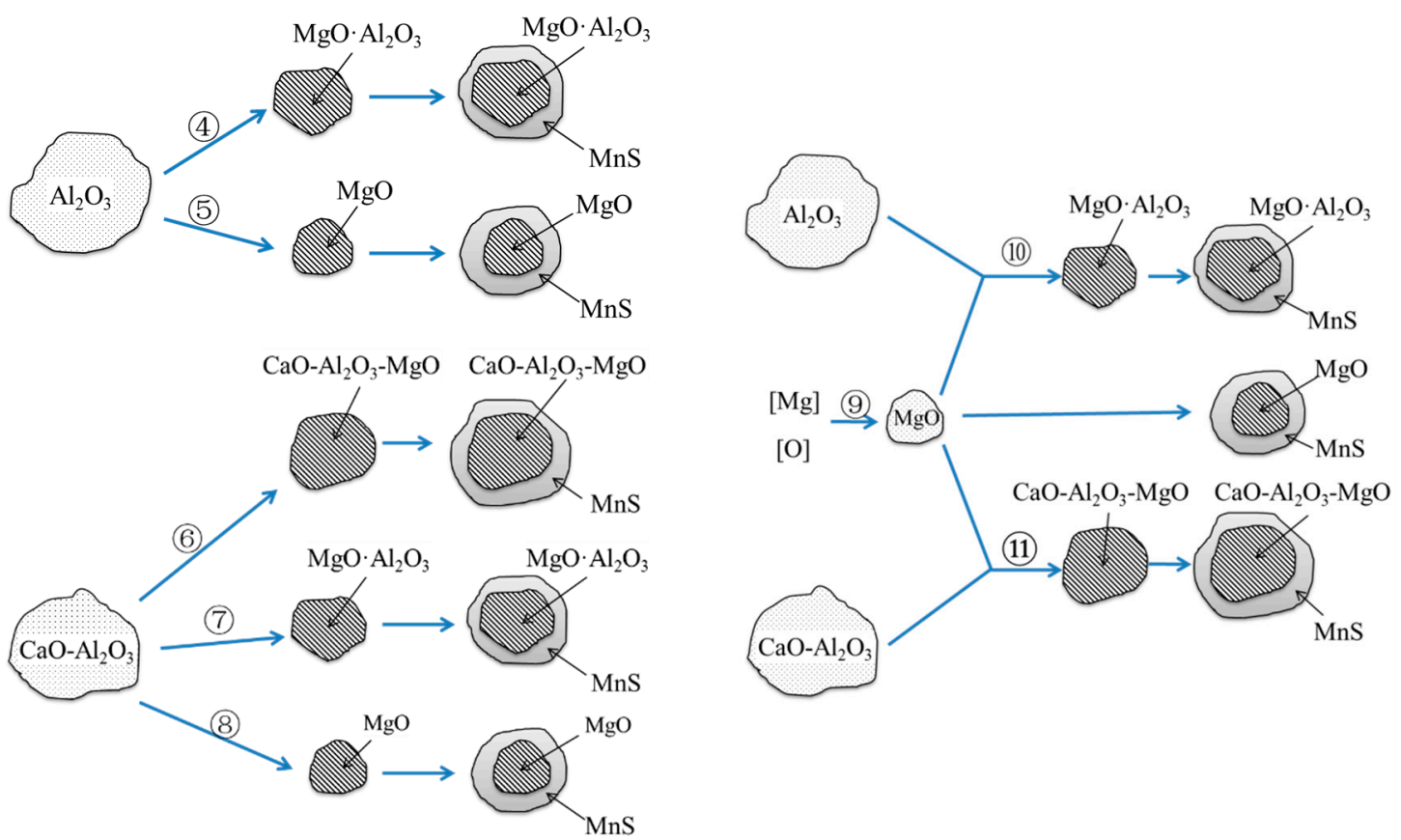

(a)

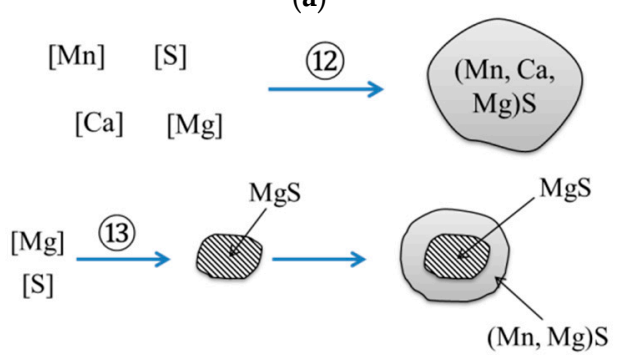

(b)

Figure 8. Mechanism of the modification of inclusions by Mg-Ca treatment. (a) modification of oxide inclusions; (b) modification of sulfide inclusions.

Table 3. Reaction of each modification process.

\begin{tabular}{ccc}
\hline No. & Reaction & Reference \\
\hline 1 & $\mathrm{Al}_{2} \mathrm{O}_{3}+[\mathrm{Ca}] \rightarrow \mathrm{CaO}-\mathrm{Al}_{2} \mathrm{O}_{3}+[\mathrm{Al}]$ & {$[29]$} \\
2 & {$[\mathrm{Mn}]+[\mathrm{S}]+[\mathrm{Ca}] \rightarrow(\mathrm{Mn}, \mathrm{Ca}) \mathrm{S}$} & - \\
3 & {$[\mathrm{~S}]+[\mathrm{Ca}]=\mathrm{CaS}$} & {$[9,29-31]$} \\
4 & $4 \mathrm{Al}_{2} \mathrm{O}_{3}+3[\mathrm{Mg}]=3 \mathrm{MgO} \cdot \mathrm{Al}_{2} \mathrm{O}_{3}+2[\mathrm{Al}]$ & {$[9,32]$} \\
5 & $\mathrm{Al}_{2} \mathrm{O}_{3}+3[\mathrm{Mg}]=3 \mathrm{MgO}+2[\mathrm{Al}]$ & {$[32,33]$} \\
6 & $\mathrm{CaO}-\mathrm{Al}_{2} \mathrm{O}_{3}+[\mathrm{Mg}] \rightarrow \mathrm{CaO}-\mathrm{Al}_{2} \mathrm{O}_{3}-\mathrm{MgO}^{2}+[\mathrm{Ca}]$ & - \\
7 & $\mathrm{CaO}-\mathrm{Al}_{2} \mathrm{O}_{3}+[\mathrm{Mg}] \rightarrow \mathrm{MgO} \cdot \mathrm{Al}_{2} \mathrm{O}_{3}+[\mathrm{Ca}]$ & {$[29]$} \\
8 & $\mathrm{CaO}-\mathrm{Al}_{2} \mathrm{O}_{3}+[\mathrm{Mg}] \rightarrow \mathrm{MgO}+[\mathrm{Ca}]+[\mathrm{Al}]$ & - \\
9 & {$[\mathrm{Mg}]+[\mathrm{O}]=\mathrm{MgO}$} & {$[19,32]$} \\
10 & $\mathrm{Al}_{2} \mathrm{O}_{3}+\mathrm{MgO}=\mathrm{MgO} \cdot \mathrm{Al}_{2} \mathrm{O}_{3}$ & - \\
11 & $\mathrm{CaO}-\mathrm{Al}_{2} \mathrm{O}_{3}+\mathrm{MgO} \rightarrow \mathrm{CaO}-\mathrm{Al}_{2} \mathrm{O}_{3}-\mathrm{MgO}$ & - \\
12 & {$[\mathrm{Mn}]+[\mathrm{S}]+[\mathrm{Ca}]+[\mathrm{Mg}] \rightarrow(\mathrm{Mn}, \mathrm{Ca}, \mathrm{Mg}) \mathrm{S}$} & {$[18]$} \\
13 & {$[\mathrm{Mg}]+[\mathrm{S}]=\mathrm{MgS}$} &
\end{tabular}

\subsection{Transformation of Inclusions}

(1) Effect of $\mathrm{Mg}$ content

According to the composition shown in Table 1, the equilibrium phase diagrams of Al content vs. Mg content at $1550{ }^{\circ} \mathrm{C}$ were calculated by FactSage 7.2 using "FactPS", "FToxid", "FTmisc" databases, 
as shown in Figure 9. Since the calcium aluminate almost disappeared after adding a small amount of $\mathrm{Mg}$, for the convenience of analysis, the Ca was not considered in the calculation. The phase diagrams for $16 \mathrm{MnCrS5}$ and $49 \mathrm{MnVS3}$ were similar. A small amount of $\mathrm{Mg}$ could lead to the formation of spinel phase $\mathrm{MgO} \cdot \mathrm{Al}_{2} \mathrm{O}_{3}$. The further increase of $\mathrm{Mg}$ resulted in the formation of $\mathrm{MgO}$. In both steels, there was a $\mathrm{Mg}$ content range that $\mathrm{MgO}$ and $\mathrm{MgO} \cdot \mathrm{Al}_{2} \mathrm{O}_{3}$ could exist in the molten steel simultaneously. When the Mg content was high enough, MgS might also generate. However, the highest $\mathrm{Mg}$ content in the laboratory experiment was still lower than the critical condition for the formation of MgS. The EDS analysis for the inclusions proved this.

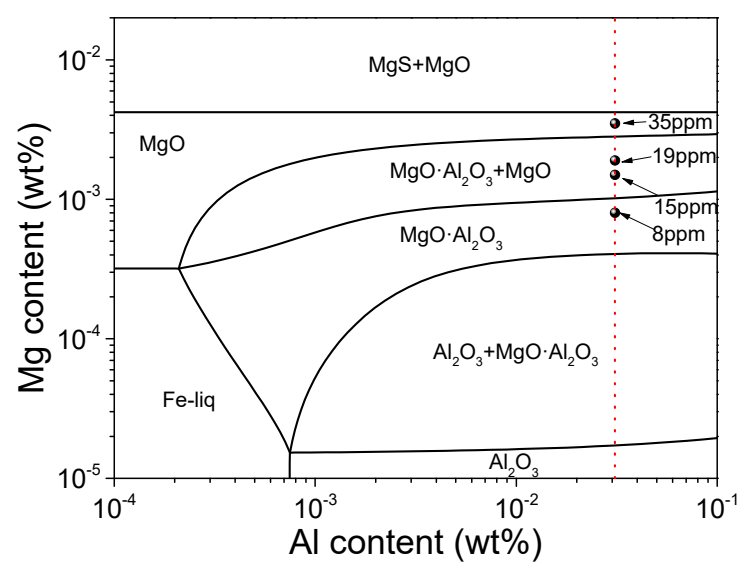

(a)

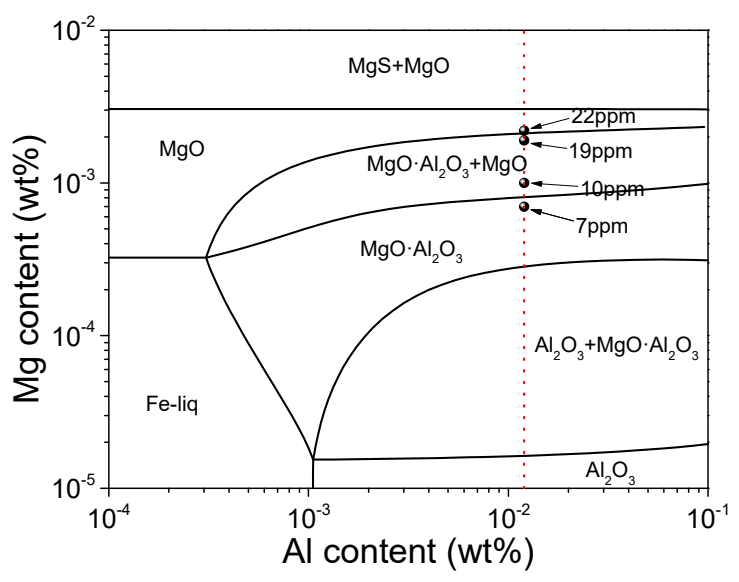

(b)

Figure 9. Equilibrium phase diagram of Mg treatment for (a) 16MnCrS5 steel; (b) 49MnVS3 steel.

\section{(2) Effect of time}

In the present study, another experiment considering the holding time was conducted to analyze the effect of time on the transformation of inclusions. Four samples were taken from the molten steel at $5 \mathrm{~min}, 10 \mathrm{~min}, 15 \mathrm{~min}$, and $20 \mathrm{~min}$, respectively, after stirring, and quenched in the water immediately. The samples were cut and polished, preparing for the SEM-EDS analysis. The $\mathrm{Mg}$ and $\mathrm{Al}$ content in the oxide cores were detected and counted. Figure 10 shows the average atom percentage of $\mathrm{Mg}$ and $\mathrm{Al}$ in the oxide cores. When the holding time increased from $5 \mathrm{~min}$ to $10 \mathrm{~min}$, the $\mathrm{Mg}$ content in the oxide core was increased, while the Al content was decreased. The further increase of holding time had little effect on the composition of oxides. Thus, the 10 min selected for the holding time after stirring could ensure the uniformity of the composition.

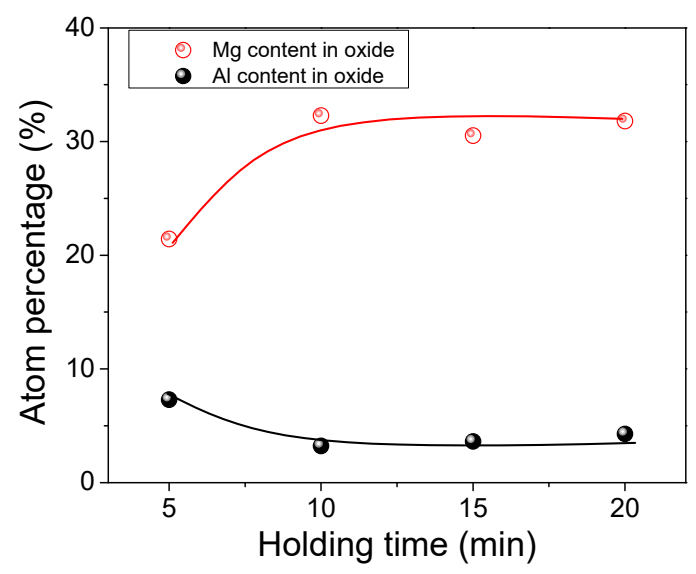

Figure 10. Effect of holding time on the composition of inclusions. 


\section{Industrial Production}

According to the laboratory study, the $\mathrm{Mg}-\mathrm{Ca}$ modification technique was applied in the manufacture of resulfurized special steel in steel plants. Figure 11 shows the photos of the application of $\mathrm{Mg}-\mathrm{Ca}$ modification in the manufacture of non-quenched and tempered steel 49MnVS3, gear steel $20 \mathrm{CrMnTiSH} 3$ and $20 \mathrm{CrMnTiH}$. The production process of each kind of steel is listed as follows:

$$
\begin{gathered}
\text { 49MnVS3: } \mathrm{EAF} \rightarrow \mathrm{LF} \rightarrow \mathrm{VD} \rightarrow \mathrm{CC} \\
\text { 20CrMnTiSH3: } \mathrm{BOF} \rightarrow \mathrm{LF} \rightarrow \mathrm{RH} \rightarrow \mathrm{CC} \\
\text { 20CrMnTiH: } \mathrm{BOF} \rightarrow \mathrm{LF} \rightarrow \mathrm{RH} \rightarrow \mathrm{CC}
\end{gathered}
$$

where EAF is electric arc furnace, LF is ladle furnace, VD is vacuum degassing, CC is continuous casting, BOF is basic oxygen furnace, RH is Ruhstahl-Hausen vacuum degassing process.

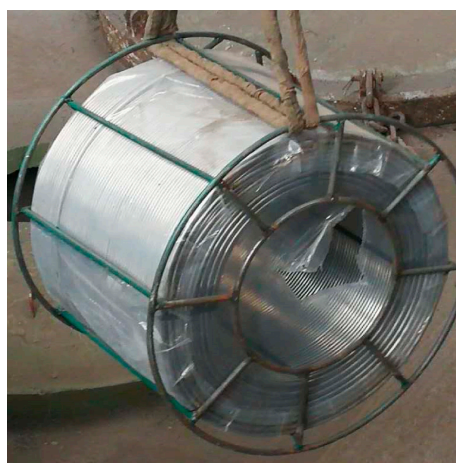

(a)

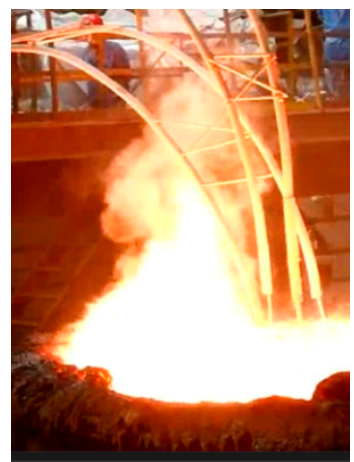

(b)

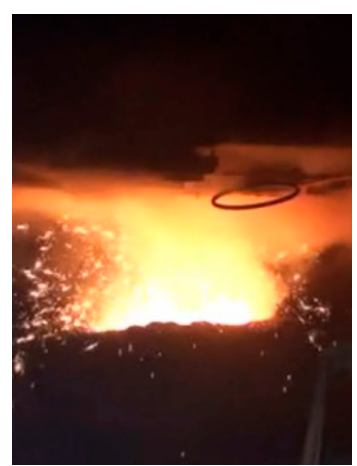

(c)

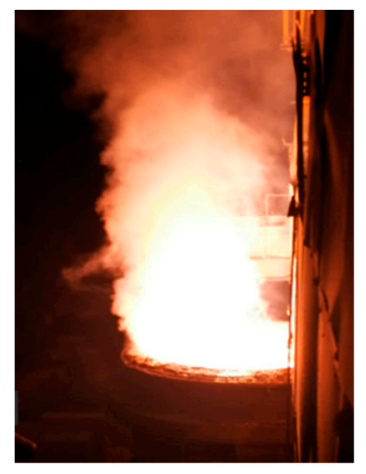

(d)

Figure 11. $\mathrm{Mg}$ treatment process in a ladle in the industrial experiment. (a) Mg-containing core-spun yarn; (b) manufacture of 49MnVS3; (c) manufacture of 20CrMnTiSH3; (d) manufacture of 20CrMnTiH.

In the following paragraphs, the analysis of the industrial experiment of non-quenched and tempered steel $49 \mathrm{MnVS} 3$ will be discussed. Table 4 shows the composition control range of the steel.

Table 4. Composition control range of 49MnVS3 steel (wt \%).

\begin{tabular}{cccccccccccc}
\hline Composition & $\mathbf{C}$ & $\mathbf{S i}$ & $\mathbf{M n}$ & $\mathbf{P}$ & $\mathbf{S}$ & $\mathbf{C r}$ & $\mathbf{V}$ & $\mathbf{N i}$ & $\mathbf{T i}$ & $\mathbf{A l}$ & $\mathbf{N}$ \\
\hline Lower limit & 0.46 & 0.25 & 0.85 & - & 0.04 & 0.15 & 0.09 & - & 0.015 & - & 0.008 \\
Upper limit & 0.49 & 0.4 & 0.95 & 0.025 & 0.06 & 0.3 & 0.12 & 0.2 & 0.03 & 0.02 & 0.02 \\
Target & 0.47 & 0.35 & 0.9 & $\leq 0.020$ & 0.05 & 0.2 & 0.1 & $\leq 0.20$ & 0.025 & 0.01 & 0.015 \\
\hline
\end{tabular}

Calcium and magnesium were added into the ladle in the form of core-spun yarn after VD refining respectively. Magnesium is an active metal and has a high saturated vapor pressure. During the feeding process, $\mathrm{Mg}$ could easily evaporate, the reaction and splashing of molten steel were relatively violent than Ca treatment. By adjusting the composition of the core-spun yarn and improving the feeding process, these two issues were controlled to an acceptable level. Steel samples with $\mathrm{Ca}$ and $\mathrm{Mg}-\mathrm{Ca}$ treatment were taken from the hot rolled steel. All samples were cut and polished, preparing for the following analysis. The $\mathrm{Ca}$ and $\mathrm{Mg}$ content in the $\mathrm{Mg}-\mathrm{Ca}$ treated steel was $8 \mathrm{ppm}$ and $5 \mathrm{ppm}$, respectively.

Figures 12 and 13 show the inclusions in the $49 \mathrm{MnVS} 3$ steel after Ca treatment and $\mathrm{Mg}-\mathrm{Ca}$ treatment captured by the optical microscope. The MnS inclusions in the Ca treated steel mainly showed strip morphology. While in the steel treated with $\mathrm{Mg}-\mathrm{Ca}, \mathrm{MnS}$ tended to keep a spherical or spindle-shaped morphology. Besides, the average equivalent diameter of inclusions decreased from $6.5 \mu \mathrm{m}$ to $5.3 \mu \mathrm{m}$. In order to evaluate the effect of $\mathrm{Mg}-\mathrm{Ca}$ treatment on the inclusions in the steels, the inclusions in both $\mathrm{Ca}$ treated steel and $\mathrm{Mg}-\mathrm{Ca}$ treated steel were determined with the standard ISO 4967: 1998. Table 5 shows the result of the assessment of sulfide inclusions in both steels. Compared 
with the Ca treatment, the assessment of sulfide inclusions after $\mathrm{Mg}-\mathrm{Ca}$ treatment was much better. The index number was approximately 0.5 lower than that of Ca treatment for both the average fine series and thick series, while for the worst fine series and thick series, the index number was 1.0 lower. Obviously, the inclusions in the steel with $\mathrm{Mg}-\mathrm{Ca}$ treatment achieved a big improvement.

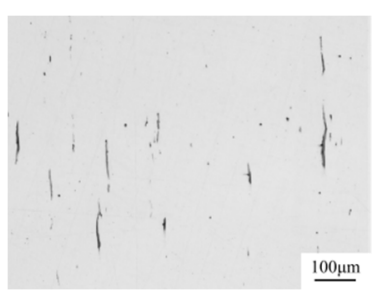

(a)

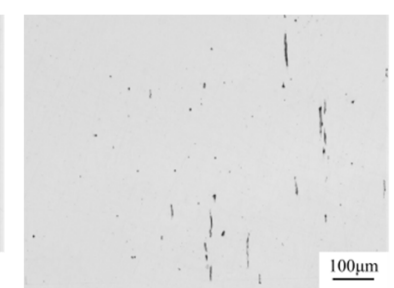

(b)

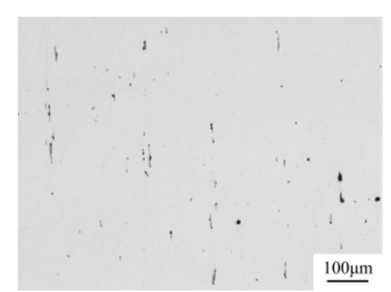

(c)

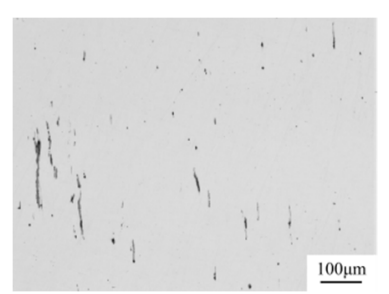

(d)

Figure 12. The inclusions in the $49 \mathrm{MnVS3}$ steel after Ca treatment: (a) image 1 ; (b) image 2; (c) image 3; (d) image 4.

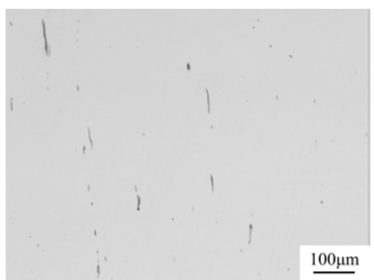

(a)

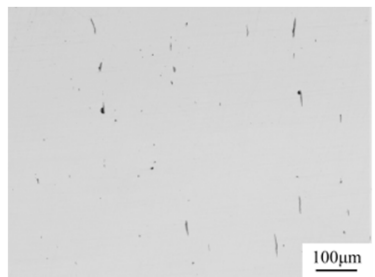

(b)

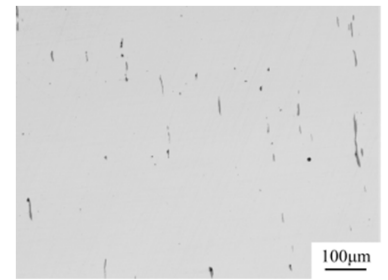

(c)

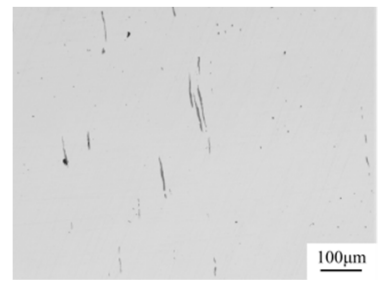

(d)

Figure 13. The inclusions in the $49 \mathrm{MnVS} 3$ steel after Mg-Ca treatment: (a) image 1; (b) image 2; (c) image 3; (d) image 4 .

Table 5. Assessment of sulfide inclusions.

\begin{tabular}{ccccc}
\hline \multirow{2}{*}{ Process } & \multicolumn{2}{c}{ Average } & \multicolumn{2}{c}{ Worst } \\
\cline { 2 - 5 } & Fine Series & Thick Series & Fine Series & Thick Series \\
\hline Ca treatment & 2.0 & 1.5 & 3.0 & 2.5 \\
$\mathrm{Mg}-$ Ca treatment & 1.5 & 1.0 & 2.0 & 1.5 \\
\hline
\end{tabular}

The inclusions in both steels were counted using Image Pro Plus 6.0 software. The statistical results are shown in Figure 14. A remarkable number increase of small inclusions could be observed, and more inclusions were in the aspect ratio range of $\sim 1-3$. Taking all the inclusions into consideration, the average statistical results of inclusions are shown in Table 6. Compared with the Ca treatment, the diameter, area fraction, and aspect ratio achieved a big decrease, while the number density increased after $\mathrm{Mg}$-Ca treatment. It meant that the additional Mg treatment could modify the inclusions to dispersive distributed tiny inclusions, providing more heterogeneous nucleation points for the precipitation of MnS. Besides, the decrease of area fraction of inclusions indicated that the steel was purified by the Mg treatment, as was the same in references [16,19]. Therefore, the Mg treatment had a significant effect on the modification of inclusions, preventing the deformation of inclusions, which was consistent with the result in the laboratory study. 


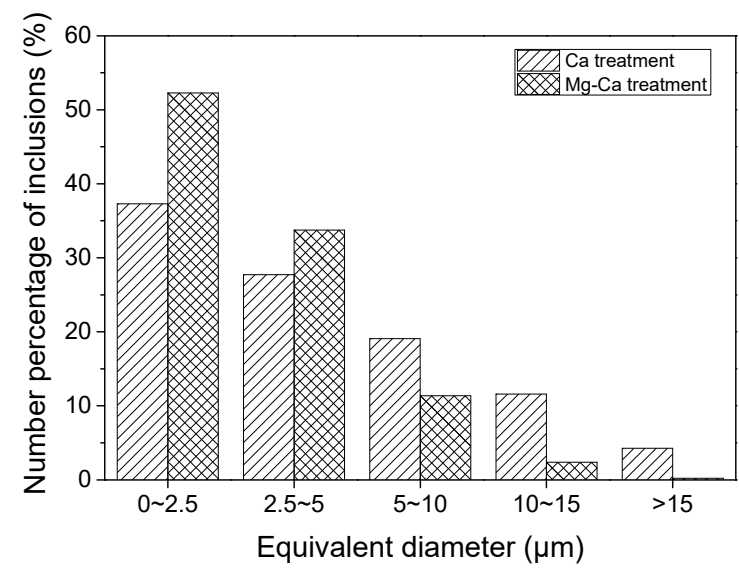

(a)

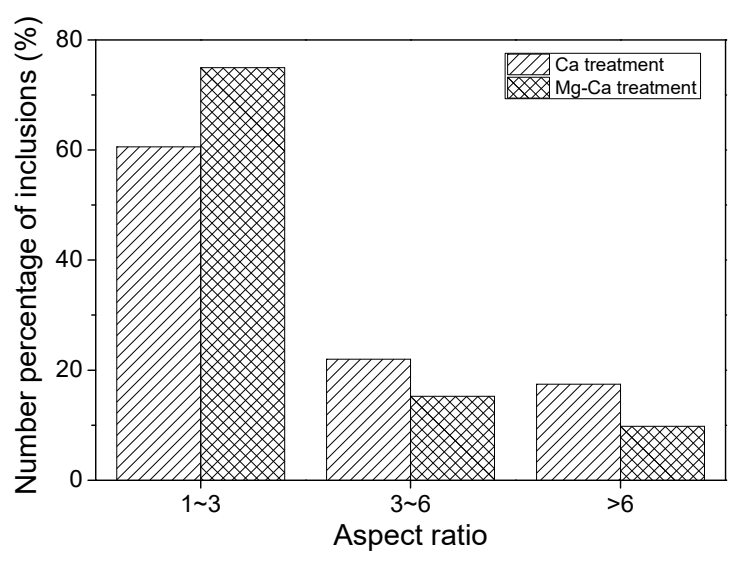

(b)

Figure 14. Number percentage of inclusions in $49 \mathrm{MnVS3}$ steel in (a) different diameter ranges; (b) different aspect ratio ranges.

Table 6. Average statistics result of inclusions.

\begin{tabular}{ccccc}
\hline Process & Diameter $(\boldsymbol{\mu m})$ & Number Density $\left(\mathbf{m m}^{-\mathbf{2}}\right)$ & Area Fraction $\mathbf{( \% )}$ & Aspect Ratio \\
\hline Ca treatment & 5.17 & 179 & 0.52 & 3.63 \\
$\mathrm{Mg}-$ Ca treatment & 3.19 & 263 & 0.25 & 2.73 \\
\hline
\end{tabular}

The steel samples were then analyzed by SEM-EDS. Figures 15 and 16 show the inclusions in steels after the two treatments. In the Ca treated steel, part of $\mathrm{Al}_{2} \mathrm{O}_{3}$ was modified to $\mathrm{CaO}-\mathrm{Al}_{2} \mathrm{O}_{3}$ inclusion, while the rest remained unchanged. In the $\mathrm{Mg}-\mathrm{Ca}$ treated steel, few $\mathrm{Al}_{2} \mathrm{O}_{3}$ and $\mathrm{CaO}-\mathrm{Al}_{2} \mathrm{O}_{3}$ could be observed, most oxide inclusions had been transformed to $\mathrm{MgO} \cdot \mathrm{Al}_{2} \mathrm{O}_{3}$. The mapping result of a complex inclusion after $\mathrm{Mg}-\mathrm{Ca}$ treatment is shown in Figure 17. As mentioned above, the $\mathrm{Mg}$ content in the steel was $5 \mathrm{ppm}$. The detection result was consistent with the previous thermodynamic analysis. This amount of $\mathrm{Mg}$ was already high enough to modify $\mathrm{Al}_{2} \mathrm{O}_{3}$.

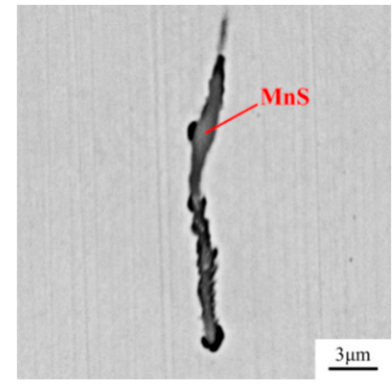

(a)

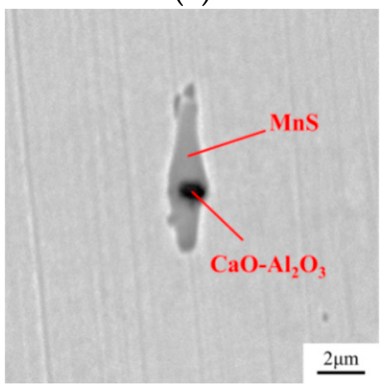

(d)

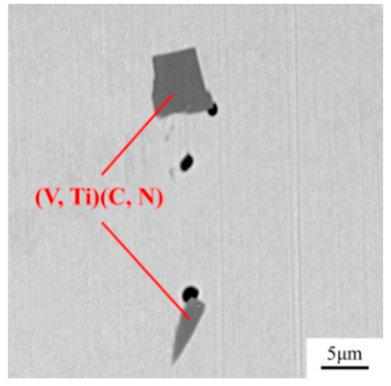

(b)

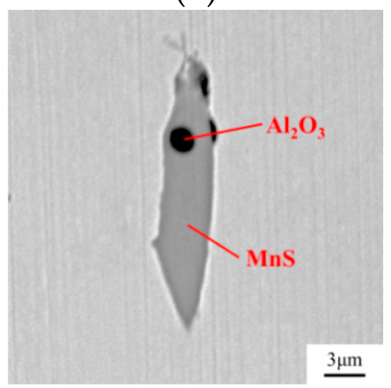

(e)

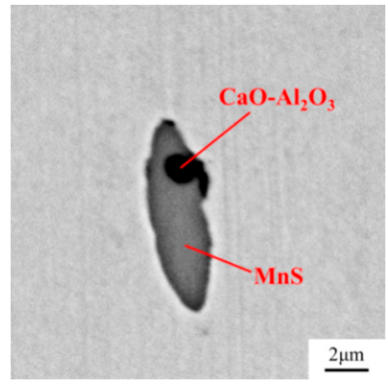

(c)

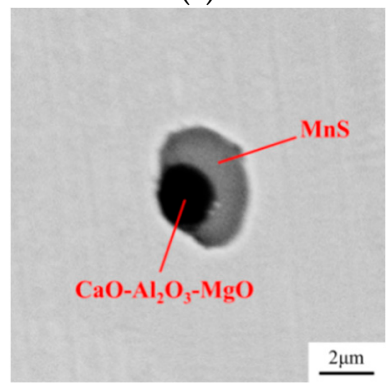

(f)

Figure 15. Compositions obtained from the EDS results of inclusions in the steel after Ca treatment. (a) $\mathrm{MnS}$; (b) $(\mathrm{V}, \mathrm{Ti})(\mathrm{C}, \mathrm{N})$; (c) $\mathrm{CaO}-\mathrm{Al}_{2} \mathrm{O}_{3}+\mathrm{MnS}$; (d) $\mathrm{CaO}-\mathrm{Al}_{2} \mathrm{O}_{3}+\mathrm{MnS}$; (e) $\mathrm{Al}_{2} \mathrm{O}_{3}+\mathrm{MnS}$; (f) $\mathrm{CaO}-\mathrm{Al}_{2} \mathrm{O}_{3}-\mathrm{MgO}+\mathrm{MnS}$. 


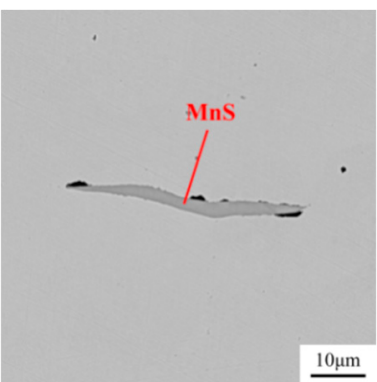

(a)

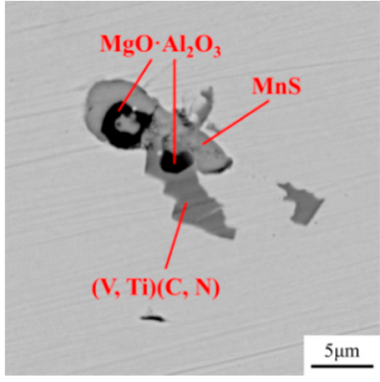

(d)

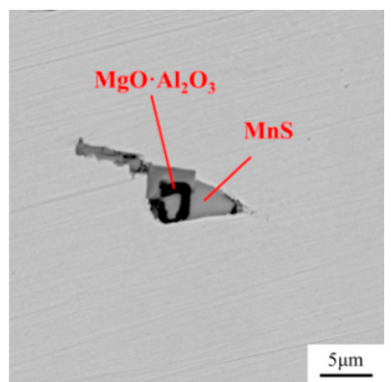

(b)

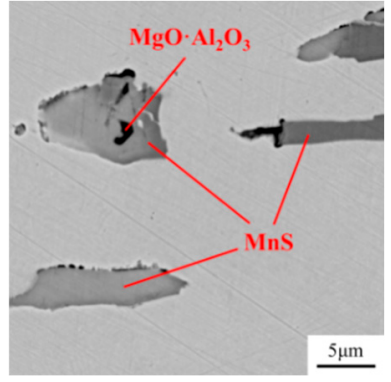

(e)

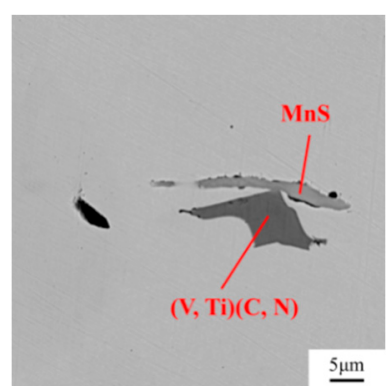

(c)

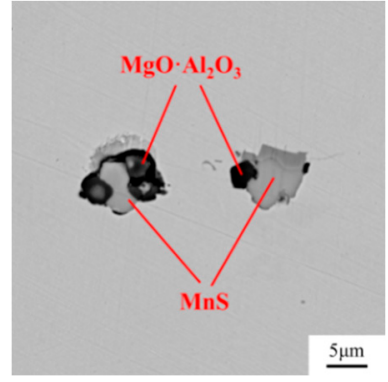

(f)

Figure 16. Compositions obtained from the EDS results of inclusions in the steel after $\mathrm{Mg}-\mathrm{Ca}$ treatment. (a) $\mathrm{MnS}$; (b) $\mathrm{MgO} \cdot \mathrm{Al}_{2} \mathrm{O}_{3}+\mathrm{MnS} ;(\mathbf{c})(\mathrm{V}, \mathrm{Ti})(\mathrm{C}, \mathrm{N})+\mathrm{MnS} ;(\mathbf{d}) \mathrm{MgO} \cdot \mathrm{Al}_{2} \mathrm{O}_{3}+\mathrm{MnS}+(\mathrm{V}, \mathrm{Ti})(\mathrm{C}, \mathrm{N})$; (e) $\mathrm{MgO} \cdot \mathrm{Al}_{2} \mathrm{O}_{3}+\mathrm{MnS}$; (f) $\mathrm{MgO} \cdot \mathrm{Al}_{2} \mathrm{O}_{3}+\mathrm{MnS}$
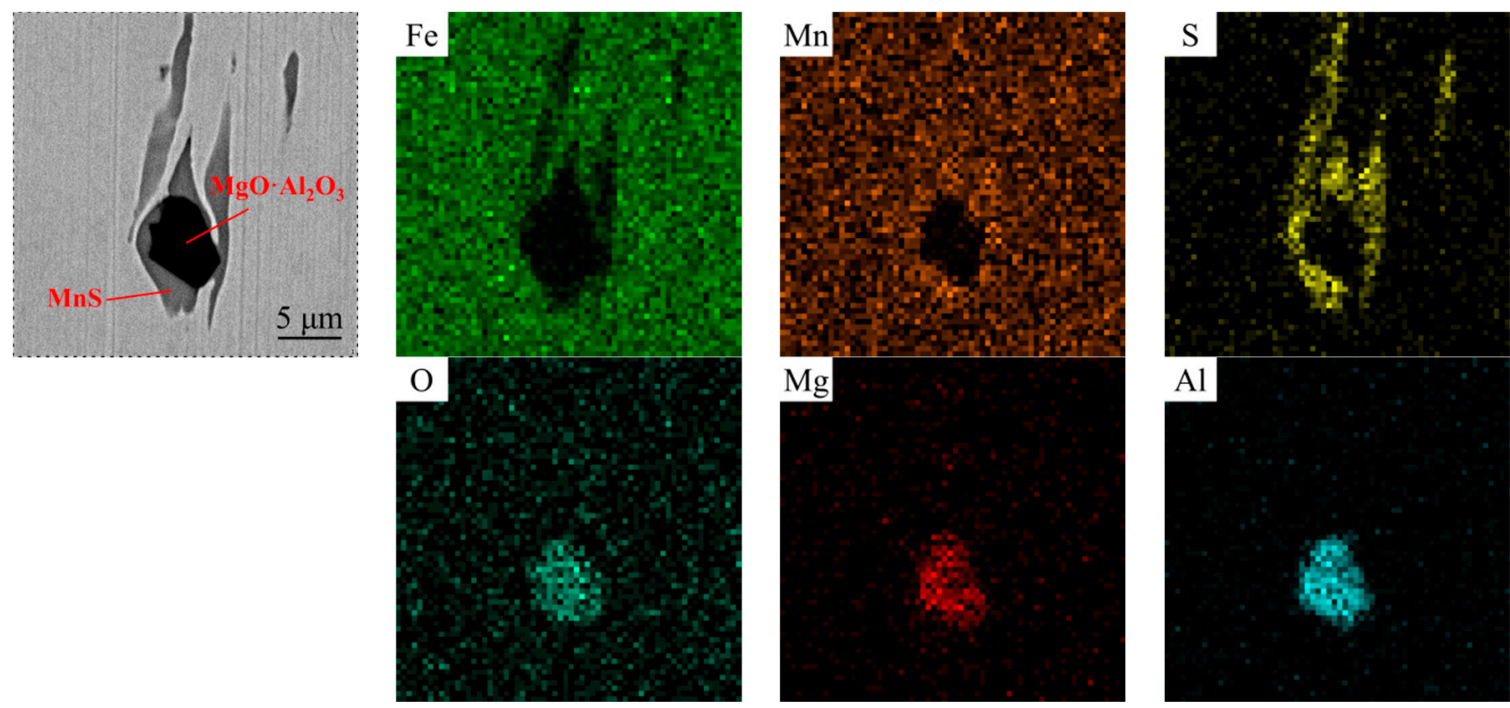

Figure 17. Mapping result of the complex inclusion after $\mathrm{Mg}-\mathrm{Ca}$ treatment.

In both steels, there was a certain amount of single-phase MnS inclusion, which tended to become a long strip. The fewer number percentage of this kind of inclusion, the better morphology of the inclusions.

The inclusions in the steels could be roughly divided into three categories, i.e., single MnS inclusion, MnS inclusion with an oxide core, and $(\mathrm{Ti}, \mathrm{V})(\mathrm{C}, \mathrm{N})$ inclusion. The number percentage of each kind of inclusion is shown in Figure 18. The number percentage of MnS inclusion with an oxide core increased from 11.6 to $23.3 \%$ with the additional Mg treatment, while that of single MnS decreased. Thus, the variation of these two kinds of inclusions proved that the $\mathrm{Mg}-\mathrm{Ca}$ treatment delivered better inclusions overall compared to the simple Ca treatment. In addition, the $(\mathrm{Ti}, \mathrm{V})(\mathrm{C}, \mathrm{N})$ inclusion seems to be not affected by the process. 


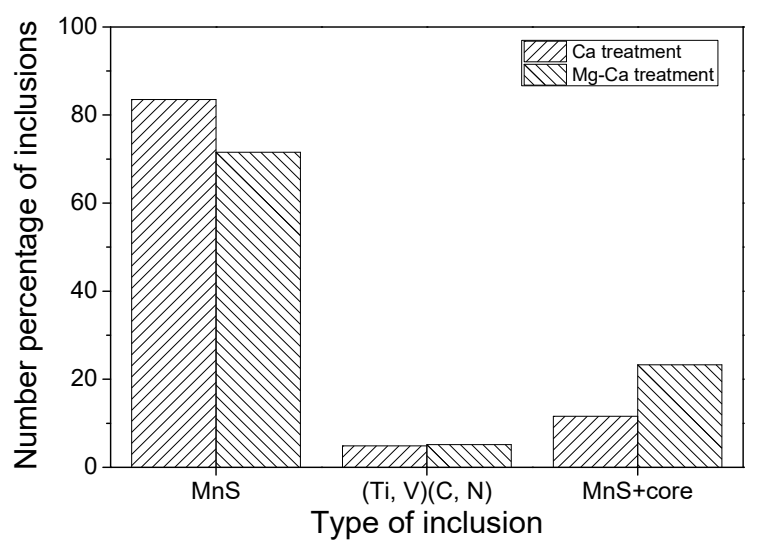

Figure 18. Number percentage of different kinds of inclusions in 49MnVS3 steel.

\section{Conclusions}

(1) In the laboratory study, $\mathrm{Ni}-\mathrm{Mg}$ alloy was added into the $\mathrm{Ca}$ treated steel. With the increase of $\mathrm{Mg}$ content, the $\mathrm{Al}_{2} \mathrm{O}_{3}$ and $\mathrm{CaO}-\mathrm{Al}_{2} \mathrm{O}_{3}$ gradually transformed to $\mathrm{MgO} \cdot \mathrm{Al}_{2} \mathrm{O}_{3}$ and $\mathrm{MgO}$. Besides, part of $\mathrm{Mg}$ dissolved into $\mathrm{MnS}$, and a solid solution was generated. The oxide inclusion was wrapped by sulfide in the solidification process, forming a complex inclusion with an oxide core and sulfide outer layer. With the increase of $\mathrm{Mg}$ content, the number percentage of complex inclusions increased, while the ratio of single MnS decreased. In addition, more inclusions transformed from type II inclusion to type III or type I inclusion.

(2) In the hot forging experiment of $16 \mathrm{MnCrS5}$ steel, the MnS inclusion without an oxide core was deformed into a long strip. While the complex inclusions showed less deformation and kept the morphology with low aspect ratio. With the increase of Mg content, the number percentage of inclusions with a small aspect ratio range increased. The addition of $\mathrm{Mg}$ had a significant influence on preventing the deformation of MnS inclusion.

(3) The $\mathrm{Mg}-\mathrm{Ca}$ modification process employed in the manufacture of non-quenched and tempered steel $49 \mathrm{MnVS3}$ indicated that the extra Mg treatment resulted in the improvement of the assessment of sulfide inclusions compared with that with only Ca treatment. More inclusions had a small size and less deformation of inclusions occurred after hot rolling. The composition and ratio of different kinds of inclusions were in agreement with that in the laboratory study.

Author Contributions: Data curation, P.S.; Investigation, P.S.; Methodology, J.F.; Project administration, J.F.; Writing-original draft, P.S.; Writing—review \& editing, J.F.

Funding: This work was supported by the National Key Research and Development Program of China (2018YFB0704400), the National Natural Science Foundation of China (51474142, 51671124, 51874195), and the China Postdoctoral Science Foundation (2018M632082).

Conflicts of Interest: The authors declare no conflict of interest.

\section{References}

1. Chang, K.; Wang, P.; Liu, W. Development status and application prospect of non-quenched tempered steel. Heat Treat. Met. 2011, 36, 80-85. [CrossRef]

2. Wu, S.; Liu, Z.; Wu, Y.; Wang, X. Production and application of gear steel in China. Spec. Steel 2003, 24, 30-33. [CrossRef]

3. Knyazeva, M.; Rozo Vasquez, J.; Gondecki, L.; Weibring, M.; Pöhl, F.; Kipp, M.; Tenberge, P.; Theisen, W.; Walther, F.; Biermann, D. Micro-magnetic and microstructural characterization of wear progress on case-hardened 16MnCr5 gear wheels. Materials 2018, 11, 2290. [CrossRef] [PubMed]

4. Pessard, E.; Morel, F.; Morel, A.; Bellett, D. Modelling the role of non-metallic inclusions on the anisotropic fatigue behaviour of forged steel. Int. J. Fatigue 2011, 33, 568-577. [CrossRef] 
5. Li, G.; Wang, F.; Hui, R.; Cao, W. Effects of sulfur addition methods and Ca-Si treatment on the microstructure and properties of 30MnVS. Int. J. Miner. Metall. Mater. 2009, 16, 650-653. [CrossRef]

6. Shao, X.; Wang, X.; Jiang, M.; Wang, W.; Huang, F. Effect of heat treatment conditions on shape control of large-sized elongated MnS inclusions in resulfurized free-cutting steels. ISIJ Int. 2011, 51, 1995-2001. [CrossRef]

7. Tsunekage, N.; Tsubakino, H. Effects of sulfur content and sulfide-forming elements addition on impact properties of ferrite-pearlitic microalloyd steels. ISIJ Int. 2001, 41, 498-505. [CrossRef]

8. Cerullo, M. Sub-surface fatigue crack growth at alumina inclusions in AISI 52100 roller bearings. Procedia Eng. 2014, 74, 333-338. [CrossRef]

9. Yang, J.; Wang, X.; Jiang, M.; Wang, W. Effect of calcium treatment on non-metallic inclusions in ultra-low oxygen steel refined by high basicity high $\mathrm{Al}_{2} \mathrm{O}_{3}$ slag. J. Iron. Steel Res. Int. 2011, 18, 8-14. [CrossRef]

10. Deng, Z.; Zhu, M. A new double calcium treatment method for clean steel refining. Steel Res. Int. 2013, 84, 519-525. [CrossRef]

11. Lind, M.; Holappa, L. Transformation of alumina inclusions by calcium treatment. Metall. Mater. Trans. $B$ 2010, 41, 359-366. [CrossRef]

12. Yan, G. Study of Technology Theory and Quality Control for Free-Cutting Machinability of Medium-Carbon-Steel; University of Science and Technology Beijing: Beijing, China, 2006.

13. Qiao, M.R.; Guo, S.Q.; Su, X.; Zheng, H.Y.; Qin, L.B. Thermodynamics on the modification of inclusions by $\mathrm{Ca}$ and Mg treatment in GCr18Mo bearing steel. Defect Diffus. Forum 2018, 382, 73-79. [CrossRef]

14. Blais, C.; L’Espérance, G.; Lehuy, H.; Forget, C. Development of an integrated method for fully characterizing multiphase inclusions and its application to calcium-treated steels. Mater. Charact. 1997, 38, 25-37. [CrossRef]

15. Ren, Y.; Zhang, Y.; Zhang, L. A kinetic model for Ca treatment of Al-killed steels using FactSage macro processing. Ironmak. Steelmak. 2016, 44, 497-504. [CrossRef]

16. Jiang, Z.; Zhuang, Y.; Li, Y.; Li, S. Effect of modification treatment on inclusions in 430 stainless steel by Mg-Al alloys. J. Iron. Steel Res. Int. 2013, 20, 6-10. [CrossRef]

17. Kimura, S.; Nakajima, K.; Mizoguchi, S. Behavior of alumina-magnesia complex inclusions and magnesia inclusions on the surface of molten low-carbon steels. Metall. Mater. Trans. B 2001, 32, 79-85. [CrossRef]

18. Zhang, T.; Wang, D.; Liu, C.; Jiang, M.; Lv, M.; Wang, B.; Zhang, S. Modification of inclusions in liquid iron by Mg treatment. J. Iron. Steel Res. Int. 2014, 21, 99-103. [CrossRef]

19. Fu, J.; Yu, Y.; Wang, A.; Chen, B. Inclusion modification with Mg treatment for 35CrNi3MoV steel. J. Mater. Sci. Technol. 1998, 14, 53-56. [CrossRef]

20. Oikawa, K.; Ohtani, H.; Ishida, K.; Nishizawa, T. The control of the morphology of MnS inclusions in steel during solidification. ISIJ Int. 2007, 35, 402-408. [CrossRef]

21. Zhang, X.; Zhang, L.; Yang, W.; Dong, Y. Characterization of MnS particles in heavy rail steels using different methods. Steel Res. Int. 2017, 88, 1600080. [CrossRef]

22. Ånmark, N.; Karasev, A.; Jönsson, P.G. The effect of different non-metallic inclusions on the machinability of steels. Materials 2015, 8, 751-783. [CrossRef]

23. Yang, J.; Yamasaki, T.; Kuwabara, M. Behavior of inclusions in deoxidation process of molten steel with in situ produced Mg vapor. ISIJ Int. 2007, 47, 699-708. [CrossRef]

24. Zhang, T.; Wang, D.; Zhang, Y.; Jiang, M. Dynamic evolution of inclusions in Al-Mg deoxidation melts. J. Northeast. Univ. 2014, 35, 1270-1274. [CrossRef]

25. Shen, P.; Yang, Q.; Zhang, D.; Yang, S.; Fu, J. The effect of tellurium on the formation of MnTe-MnS composite inclusions in non-quenched and tempered steel. Metals 2018, 8, 639. [CrossRef]

26. Ye, G.; Jonsson, P.; Lund, T. Thermodynamics and kinetics of the modification of $\mathrm{Al}_{2} \mathrm{O}_{3}$ inclusions. ISIJ Int. 1996, 36, S105-S108. [CrossRef]

27. Duan, Y.; Chen, X.; Wang, Y. Causes analysis and improvements of tundish nozzle clogging for aluminized steel. Iron Steel Vanadium Titanium 2015, 36, 123-127. [CrossRef]

28. Fujii, K.; Nagasaka, T.; Hino, M. Activities of the constituents in spinel splid solution and free energies of formation of $\mathrm{MgO}, \mathrm{MgO} \cdot \mathrm{Al}_{2} \mathrm{O}_{3}$. Trans. Inst. Iron Steel Inst. Jpn. 2000, 40, 1059-1066. [CrossRef]

29. Holappa, L.; HäMäLäinen, M.; Liukkonen, M.; Lind, M. Thermodynamic examination of inclusion modification and precipitation from calcium treatment to solidified steel. Ironmak. Steelmak. 2002, 30, 111-115. [CrossRef] 
30. Xu, J.; Huang, F.; Wang, X. Formation mechanism of CaS- $\mathrm{Al}_{2} \mathrm{O}_{3}$ inclusions in low sulfur Al-killed steel after calcium treatment. Metall. Mater. Trans. B 2016, 47, 1217-1227. [CrossRef]

31. Verma, N.; Pistorius, P.C.; Fruehan, R.J.; Potter, M.; Lind, M.; Story, S. Transient inclusion evolution during modification of alumina inclusions by calcium in liquid steel: Part I. Background, experimental techniques and analysis methods. Metall. Mater. Trans. B 2011, 42, 711-719. [CrossRef]

32. Yang, S.; Wang, Q.; Zhang, L.; Li, J.; Peaslee, K. Formation and modification of $\mathrm{MgO} \cdot \mathrm{Al}_{2} \mathrm{O}_{3}$-based inclusions in alloy steels. Metall. Mater. Trans. B 2012, 43, 731-750. [CrossRef]

33. Okuyama, G.; Yamaguchi, K.; Takeuchi, S.; Ken-Ichi, S. Effect of slag composition on the kinetics of formation of $\mathrm{Al}_{2} \mathrm{O}_{3}-\mathrm{MgO}$ inclusions in aluminum killed ferritic stainless steel. ISIJ Int. 2000, 40, 121-128. [CrossRef]

34. Itoh, H.; Hino, M.; Ban-Ya, S. Thermodynamics on the formation of spinel nonmetallic inclusion in liquid steel. Metall. Mater. Trans. B 1997, 28, 953-956. [CrossRef]

35. Jo, S.K.; Kim, S.H.; Bo, S. Thermodynamics on the formation of spinel $\left(\mathrm{MgO} \cdot \mathrm{Al}_{2} \mathrm{O}_{3}\right)$ inclusion in liquid iron containing chromium. Metall. Mater. Trans. B 2002, 33, 703-709. [CrossRef]

(C) 2019 by the authors. Licensee MDPI, Basel, Switzerland. This article is an open access article distributed under the terms and conditions of the Creative Commons Attribution (CC BY) license (http:/ / creativecommons.org/licenses/by/4.0/). 